Article

\title{
Behavioural Aspects of Office Space Structures in the City: The Case of Warsaw's Business Districts
}

\author{
Dorota Celińska-Janowicz *, Maciej Smętkowski and Katarzyna Wojnar \\ Centre for European Regional and Local Studies (EUROREG), University of Warsaw, Poland; \\ E-Mails: d.celinska@uw.edu.pl (D.C.-J.), m.smetkowski@uw.edu.pl (M.S.), k.wojnar@uw.edu.pl (K.W.) \\ * Corresponding author
}

Submitted: 8 March 2021 | Accepted: 10 June 2021 | Published: 23 September 2021

\begin{abstract}
Agglomeration and urbanisation externalities accelerate the concentration of commercial activities in the urban space and the creation of business districts. As a result, besides the usual central business district (CBD), large cities also have more recent, peripheral, and specialised secondary business districts (SBDs). There is little substantial research on the formation of SBDs in rapidly globalising, semi-peripheral locations, especially in post-socialist metropolises of Central and Eastern Europe. This includes Warsaw, Poland, which is being transformed into an emerging global metropolis. The article aims to determine the differences between the CBD and the SBD in Warsaw in terms of their attractiveness to companies and employees and the spatial behaviours of employees, especially in terms of transport and shopping. The research hypotheses indicate the differences between the two districts in terms of the type of agglomeration economies, transport accessibility, and components of the competitive advantage, as well as the characteristics of companies in those districts. The data are from a survey conducted in 2017-2018 among companies and their employees in both business districts, and they are analysed using basic statistical techniques and discriminatory analysis. The results confirmed there are significant differences between the two Warsaw business areas, mainly in terms of their transport accessibility and urbanisation externalities. In terms of transport, there is a greater role for public transport and rail in the CBD and for motorway and airport proximity in the SBD. Urbanisation externalities are significantly diminished by the traffic congestion in the SBD. The study also revealed that the development of commercial areas in Warsaw-a post-socialist city with a neoliberal model of spatial planning-follows only in some aspects the spatial patterns of business areas in other Western European metropolises.
\end{abstract}

\section{Keywords}

central business district; location factor; secondary business district; spatial behaviour; Warsaw

\section{Issue}

This article is part of the issue "Future Commercial and Industrial Areas" edited by Angela Million (TU Berlin, Germany) and Felix Bentlin (TU Berlin, Germany).

(C) 2021 by the authors; licensee Cogitatio (Lisbon, Portugal). This article is licensed under a Creative Commons Attribution 4.0 International License (CC BY).

\section{Introduction}

The new development paradigm of the information economy increases the role of information and communication technologies (ICT), creativity, and innovation as key factors of the competitiveness of an enterprise. Despite the decrease in transport costs, the importance of space-understood not so much as a specific area or region, but as various forms of proximity and relationships-increases in the processes of economic development. Metropolisation, as a territorial dimension of the information economy, creates a global network of large cities that act as nodes for the flow of goods, people, capital, information, and ideas (Castells, 1998). Metropolises offer agglomeration economies favourable for creating new knowledge, innovative technologies (Hardt \& Negri, 2000), and creative solutions (Florida, 2005; Wojnar, 2016).

Control and management functions of the global information economy are often concentrated in urban 
centres and metropolitan regions (Castells, 1998), where spatial structure is characterised by the deconcentration of economic activity (Criekingen et al., 2007; Hall \& Pain, 2006). Such deconcentration and decentralisation may take the form of a chaotic sprawl (Lang, 2003) or a "concentrated dispersion" (Filion, 2000). The result is a polycentric metropolitan structure. In this process, new economic spaces are created, such as business districts outside the city centre or clusters of technologically advanced and creative industries. The emergence of new types of economic areas may eventually weaken the traditional city centre and create polycentric metropolitan structures in which traditional central business districts (CBDs) still play an important role but are accompanied by the secondary business districts (SBDs), also in the form of edge cities (Garreau, 1991) or other urban or suburban structures (Bole, 2010; Hall, 1999; Ratcliffe et al., 2009).

The new development paradigm of the fourth industrial revolution is related to decentralised and adaptive management of the manufacturing process (Hermann et al., 2016). In the knowledge-based economy (Rutten \& Boekema, 2012), the dichotomy between the product and the service blurs (Kotler, 1994), while innovation is increasingly related to advanced business services (Doloroux \& Shearmur, 2013). These types of economic activities become concentrated especially in central and secondary business areas that become increasingly important topics of contemporary urban development research (Glaeser, 2011). CBDs and SBDs develop and operate in different ways (Spencer, 2015). City centres are usually more multifunctional and offer better access to a range of cultural services and institutions. As a result, they often experience gentrification. SBDs, in turn, usually result from suburbanisation, are based more on individual transport, and are characterised by a clear separation of places of work and residence.

The general aim of the article is to determine the differences between CBDs and SBDs in terms of their attractiveness for companies and employees, as well as spatial behaviours of the latter, especially in terms of transport and shopping. The selected case study in Warsaw, Poland, allows such an analysis in the specific context of a post-socialist city (e.g., Stanilov, 2009) that has recently been transformed into an emerging global metropolis (Gorzelak \& Smętkowski, 2012; Korcelli-Olejniczak, 2007; Taylor et al., 2010). Section 2 provides a review of the literature relevant to the aim of this article and is followed by Section 3, which is the presentation of both Warsaw's business districts. Section 4 contains basic information about the research methodology and data, while Section 5 presents the results of the analysis. The article closes with a discussion and conclusion, which includes recommendations for spatial development policy and planning.

\section{Literature Review}

The dynamic development of ICT fosters the polycentricity of contemporary urban regions (Hall \& Pain, 2006).
Decreasing communication costs allow large advanced producer services companies to locate routine functions outside the city centre. This may lead to a decrease of that area's role and importance (Fujita \& Thisse, 2002). The process may create two labour markets: the primary one concentrates front-office functions in the CBD, and the secondary one performs back-office functions in the SBD. The distribution of jobs in those business areas determines commuting patterns and transport network load. The spatial structure and characteristics of the office real estate market are crucial for the city's external connections and its position in the global network of metropolises. The location of business areas also affects the scale and type of agglomeration economies they offer. All these factors result in the significant importance of the location and characteristics of business districts for urban spatial and development planning and policy (Smętkowski et al., 2019, 2020). In this context, European edge cities differ from those in the USA because of the greater involvement of the public sector in their development. That is, they are more planned than spontaneous. European edge cites are also not fully independent of the traditional city core; they are often nearer to the existing CBD (Bontje \& Burdack, 2005).

Agglomeration effects in the form of urbanisation economies (Jacobs, 1961, 1969) offered by the CBD result from access to infrastructure and business and public institutions, proximity to other companies (including clients, suppliers, and collaborators), and the possibility of face-to-face contact (Hall \& Pain, 2006). These facilitate information flow and tacit knowledge exchange (Polanyi, 1958). Access to other advanced services and a highly qualified workforce (Martinelli \& Moulaert, 1993) is accompanied by greater control and management functions in the form of headquarters (Śleszyński, 2004, 2007). While routine functions (at the metropolitan or global scale) are deconcentrated (including offshoring), the most advanced and strategic services still require central locations (Halbert, 2007). Relations with clients during the strategic phases of negotiations and adjusting services usually take place in the $\mathrm{CBD}$, while contacts during implementation phase may be less frequent and remote. Thus, they are more appropriate for the SBD (Fujita \& Ogawa, 1982). Location preferences of companies may therefore vary depending on their specialisation (Soja, 2000).

Location factors and structural characteristics of the SBD differ from the traditional CBD (Buisson et al., 2001; Capelle-Blancard \& Tadjeddine, 2010; Criekingen et al., 2007), although they are usually driven by the same forces (Giuliano et al., 2012). Based on the results of prior research, we might expect that a CBD is characterised by the greater presence of headquarters and companies preferring face-to-face business contacts, while the presence of more routine services and companies using ICT for business contacts is typical for an SBD. The CBD specifically offers greater diversity and density of activities and functions providing the companies with positive effects 
of urbanisation economies. The SBD is expected to exploit the role of location economies related to the proximity of same sector companies (location economies also known as Marshall-Arrow-Romer externalities; Arrow, 1962; Marshall, 1920; Romer, 1986). The main components of the location attractiveness of the CBD are prestige, transport accessibility for clients, and access to public transport and rail. For the SBD, location attractiveness is based more on the cost of office space, accessibility for employees, and proximity to the airport and/or motorway (Buisson et al., 2001; Capelle-Blancard \& Tadjeddine, 2010; Criekingen et al., 2007; Giuliano et al., 2012).

Table 1 presents the summary of differences between business districts, including agglomeration economies, transport accessibility, and components of competitive advantage and company characteristics. These differences are the basis for the research hypothesises for Warsaw as a specific case of a post-socialist city. Central and Eastern European (CEE) metropolises provide interesting examples of location patterns that resulting from a combination of post-socialist heritage and the neoliberal model of spatial planning (Tsenkova \& Nedović-Budić, 2006). However, there has been no comprehensive research on this topic to the best of our knowledge.

There are several reasons to expect that Warsaw might differ from other Western European metropolises in terms of its CBD and SBD. The first premise (H1) is related to the weakness of the city centre resulting from the heritage of the socialist model of urban development, which did not consider bid rent and offered poor quality public spaces (Węcławowicz, 1996). As a result, companies might not find the prestige of inner-city locations sufficient, and the potential benefits of face-to-face interaction might be seen as limited. The second reason $(\mathrm{H} 2)$ is related to development that depends on foreign capital (Büdenbender \& Aalbers, 2019). Foreign investors tend to have specific preferences, like proximity to an international airport. As companies may choose both types of locations simultaneously, the type of external accessibility might not be a differentiating factor in the overall evaluation of locations. This could also result in locating both the back-office and the Polish and macro-regional headquarters of CEE market in the SBD. Taking this into account, we do not expect major differences between the two areas in terms of the importance of transport accessibility for customers and employees. The third premise $(\mathrm{H} 3)$ is related to the neo-liberal spatial planning environment (Smętkowski et al., 2020). It manifests itself as a significant concentration of office space in the Warsaw SBD (25\%) while other major Western SBDs, like La Défense in Paris, do not exceed $10 \%$ of overall city office space. This massive concentration might hypothetically contribute to the occurrence of urbanisation economies in the SBD as well. The last hypothetical difference $(\mathrm{H} 4)$ comes from the unique features of postsocialist cities, the greater significance of private cars for commuting. Because of inner and outer urban sprawl and a decline in the role of public transport, the car is identified with greater reliability and social prestige (Komornicki, 2011). Therefore, the car might be the dominant mode of transport regardless of the type of business district.

\section{Business Districts in Warsaw}

The post-socialist heritage of the Warsaw metropolis is an important point of reference for its contemporary transformations, including the formation and dynamics of the spatial structure and development of business districts. The most important changes in post-socialist cities are the commercialisation of the city centre; deconcentration of shopping, entertainment, and office facilities (Sýkora, 2009); revitalization of post-industrial areas; and commercial and residential suburbanisation. Neoliberal and ineffective spatial planning often leads to the creation of poorly connected monofunctional areas, including SBDs (Smętkowski et al., 2020; Sýkora \& Bouzarovski, 2012). Warsaw is not only the capital and the largest city in Poland: it is also an important regional metropolis that plays a significant role in the CEE office market, exhibits all processes mentioned above, and suffers from all their negative consequences.

Warsaw is becoming increasingly important as a global advanced producer services node, quickly advancing from a gamma-class city (Beaverstock et al., 1999) to an alpha-class world city (Taylor \& Derudder, 2016). Despite its strong regional position, the city, similar to other post-socialist metropolises, is still clearly inferior to the core European metropolises (ESPON FOCl,

Table 1. Key differences between CBD and SBD location/attractiveness factors based on the literature review.

\begin{tabular}{ccc}
\hline Differentiating factors & CBD & SBD \\
\hline Competitive advantage & Prestige & Price \\
Functional specialisation & Control & Routine services \\
Main form of business contacts & Face-to-face contacts & ICT \\
Agglomeration economies & Urbanisation economies & Location economies \\
Intraurban accessibility & Transport accessibility for clients & Transport accessibility for employees \\
Main mode of intraurban transport & Public transport & Car \\
Main type of external accessibility & Rail & Motorway, airport \\
\hline
\end{tabular}


2010). Both the size and the internationalisation of the largest corporations in CEE are much smaller than those in highly developed countries (Gorzelak \& Smętkowski, 2012; Raźniak et al., 2018). Despite the increasing importance of the command-and-control functions in CEE capital cities (Dorocki et al., 2019), significant dominance of subsidiaries rather than headquarters of large international companies and increasing market penetration by global corporations (CB Richard Ellis, 2011; Taylor, 2001) are accompanied by much less advanced knowledgeeconomy functions. Thus, modern innovation districts and technology parks are rather scarce (Benko, 1993; Dyker \& Radosevic, 1999; Komninos, 2008).

The distribution of office space in Warsaw is characterised by a very clear bipolar pattern (Smętkowski \& Celińska-Janowicz, 2014). The CBD has developed dynamically, especially in the 1990s (Śleszyński, 2004), while the SBD began to develop in the first decade of the 21st century in the post-industrial areas of Sluzewiec district about six kilometres from the city centre (Smętkowski, 2009).

The total office space in Warsaw increased from 0.4 million $\mathrm{m}^{2}$ in the mid-1990s to over 5.3 million $\mathrm{m}^{2}$ in
2016. Of this, 1.8 million $\mathrm{m}^{2}$ was in the CBD, and 1.1 million $\mathrm{m}^{2}$ in the SBD (Smętkowski et al., 2019). The spatial structure is thus clearly bipolar. Warsaw's CBD covers about $6.35 \mathrm{~km}^{2}$ and is located mainly in the central districts of Srodmiescie and Wola (Figure 1). The core of the SBD covers $3.36 \mathrm{~km}^{2}$ and is in the western part of the Mokotów district (the largest Warsaw district, mostly residential) in the southern part of the city, near the airport and the motorway ring road. Our delimitation of the two areas was based on the cartographic distribution of modern office space in Warsaw taking into account approximately 500 office buildings or their complexes.

The development of the Warsaw SBD area was not planned by local authorities. This is different from cities such as Paris (La Défense), London (Canary Wharf), Amsterdam (Zuidas), and Copenhagen (Ørestad). An extensive volume of office space, comparable to the $\mathrm{CBD}$, emerged because of market forces and the decisions of developers who preferred very cheap and readily available land rather than more expensive CBD plots, which often had undefined legal and ownership status. Spatial planning in this context was a facilitating factor since, during the SBD's most dynamic development

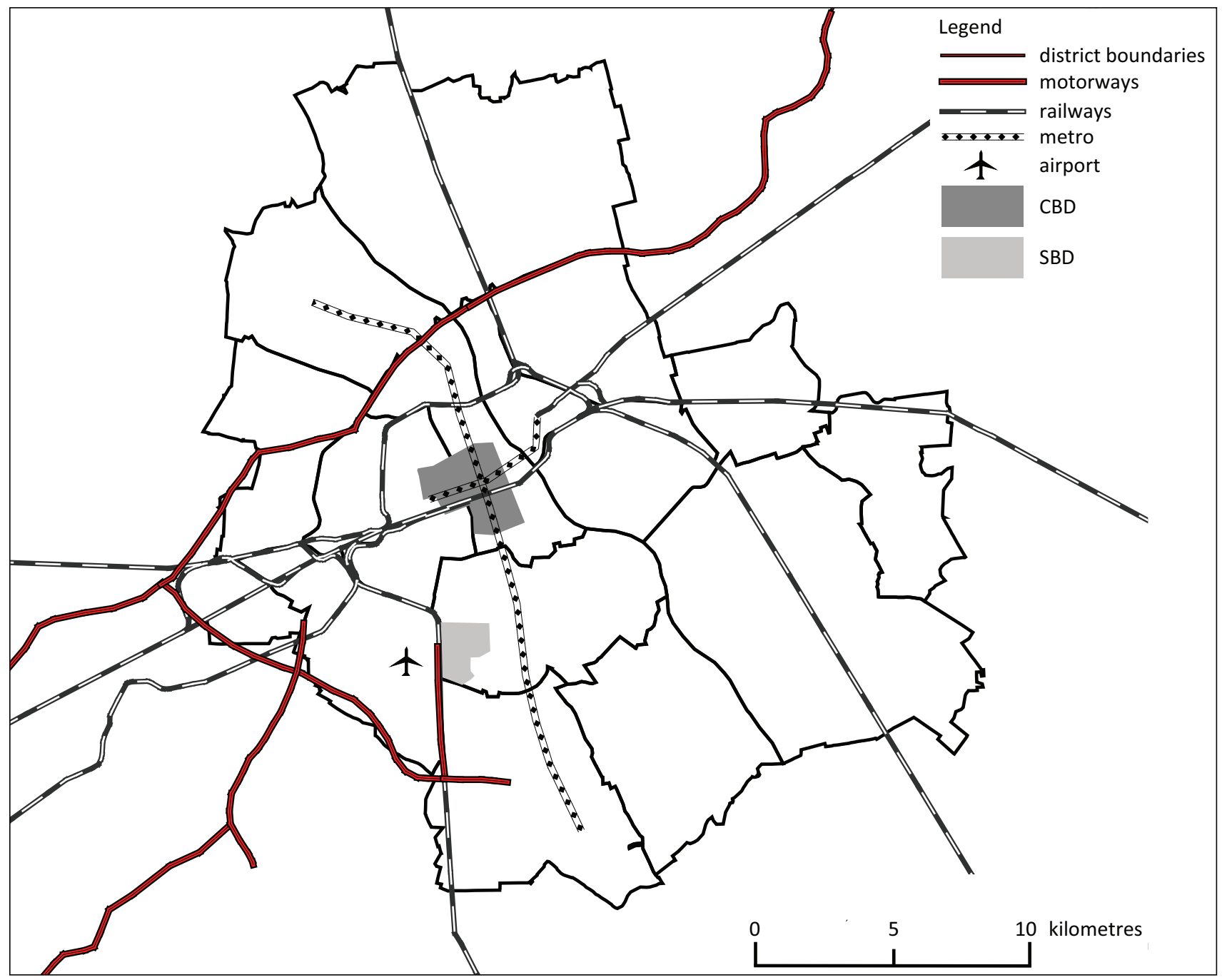

Figure 1. Location of the CBD and SBD in Warsaw. 
(2004-2013), no local spatial plans were in force for the area, leaving significant freedom for developers (Smętkowski et al., 2020). There is a large modern shopping centre in each business district: Złote Tarasy in the CBD and Galeria Mokotów in the SBD. Both are similar in size (ca. $65,000 \mathrm{~m}^{2}$ gross leasable area) and tenant mix, but Galeria Mokotów is seven years older and has been expanded three times since its opening in 2000.

\section{Data and Methods}

The empirical material for the quantitative analysis of spatial behaviours and preferences of companies and employees in two Warsaw business districts came from surveys conducted in 2017-2018 (both questionnaires are available on request; the key questions are presented in Tables 1 and 2 in the Supplementary File).

The company survey was conducted online based on the InfoCredit database of over 40,000 economic entities. The survey had two rounds. In the first round, the survey was sent to all companies. In the second round, companies were selected to create a stratified sample, i.e., to ensure a balanced geographical and branch structures. Of the 338 completed surveys, 99 came from companies in the CBD, and 62 from SBD. Of these companies, $76 \%$ in each area were established before 2010 . They employed almost 27,000 employees in Poland and 6,854 in Warsaw offices $(4,268$ at companies in the CBD, and 2,586 at companies in the SBD). In both areas, $48 \%$ of companies could be classified as micro-enterprises (excluding sole traders), hiring fewer than 10 employees. In the CBD, the average office size was $583 \mathrm{~m}^{2}$, but $44.4 \%$ of companies had office space of $100 \mathrm{~m}^{2}$ or less. In the SBD, the average was $492 \mathrm{~m}^{2}$, and $35.5 \%$ had office space of $100 \mathrm{~m}^{2}$ or less.

Among the enterprises, the highest shares were of advanced business services, both "traditional" (law, accounting, consulting; $38 \%$ in the CBD, $29 \%$ in the SBD) and "creative" (IT, advertising, architecture; $24 \%$ in the CBD, $40 \%$ in the SBD). They also belonged to the finance, insurance, and real estate sectors (17\% in the CBD, $13 \%$ in the SBD). Compared to the structure of the general population in these business areas, the sample was overrepresented by larger companies and companies that have been in business longer, and a significant overrepresentation of companies provided advanced business services. This reflects the specificity of office tenants that, even if they represented traditional sectors of the economy, were usually head offices, mostly in manufacturing, trade, or logistics companies. Furthermore, it should be emphasised that the sample reflected very well the specialisation of the two business areas; they had location quotients very close to those in the general population.

The employee survey was conducted in a direct form. At 10 locations in each business district, people who were leaving office buildings during lunch breaks or after work were approached at random and asked to complete the survey. The return rate was similar in both areas: 99 responders from SBD and 97 from $C B D$. Of the responders, $58 \%$ in the CBD and $67 \%$ in the SBD were male; $68 \%$ in CBD and $54 \%$ in SBD were 30 years old or less; and $70 \%$ in the CBD and 66\% in SBD worked in their current workplace for less than two years.

The results of both surveys were analysed using several statistical methods. A frequency analysis was used to determine the most common features of the companies and employees' behaviours and preferences. To identify differences between the two districts, a few other methods were adopted, depending on the character of the variables (dichotomous, ordinal, continuous): Chi-square test, Mann-Whitney test, and t-test of independence. Advanced linear discriminatory analysis (McLachlan, 2004) was used to identify the key factors that differentiated the CBD from the SBD. The data used in the discriminant analysis met assumptions specified for this method (Tabachnick \& Fidell, 2019).

\section{Results}

\subsection{Companies}

Based on the responses from the companies' managers, it was possible to identify the attractiveness of both business areas for local companies. The t-test showed that the attractiveness factors of the CBD were its central location, greater public transport (especially subway) and rail accessibility, the location's prestige, and rich culture and entertainment available (see Table 1 in the Supplementary File). For the SBD, the most significant advantage was proximity to the airport and the highway ring road. The attractiveness of CBDs was also shaped by greater access to shops and restaurants, while that of SBDs was shaped by the availability of parking for clients and employees and opportunities for expansion (possibility to rent more office space in the same area or to move to a larger office in the vicinity). In terms of company characteristics, the only factor that significantly differentiated the two areas was the higher frequency of ICT contacts with clients at CBD companies. Both business areas were assessed as similarly attractive in terms of the cost of office space and proximity to suppliers, clients, and same-sector companies.

To determine the differences between the two business districts in more detail, a discriminant analysis was adopted. The model that best defined differentiated the two areas had a relatively strong discriminant power (Wilks' lambda 0.419). The functions of the model enabled correct classifications based on the firms' characteristics and the responders' opinions for $91 \%$ of companies in the CBD and $85 \%$ in the SBD. This confirms there were significant differences between the $C B D$ and the SBD in terms of location preference.

The results from the discriminant analysis model showed that the main location advantage of the SBD was proximity of the ring road and the airport. This 
was attractive to large corporations that often perform control functions at headquarters. This indicated what was important to foreign investors for restructuring and development of this business area (Büdenbender \& Aalbers, 2019). Foreign companies valued access to a skilled workforce who also lived in suburban areas in the southwest part of the metropolitan area and good external accessibility because of the international airport nearby. On the other hand, the CBD was seen as more attractive in terms of proximity to the railway station. This shows, first, the importance of accessibility for employees across the metropolitan area and, second, the role of contacts within the national company structures. The locations were chosen by large corporations that might have had a complex organisational structure in Poland with production facilities outside the Warsaw metropolitan area, while their management and commercial functions operated in the city (Smętkowski et al., 2019).

The differences between the areas were also related to agglomeration economies. The SBD was distinguished by the proximity of suppliers. This may have been because of the higher density of economic actors in this economic area, while the central area was more extensive. This pattern corresponds with a higher frequency of ICT use in contacts with clients in the CBD. Also, access to cultural and entertainment facilities was considered a more important location factor in this district. In this case, however, the factor might have been perceived by the responders as a determinant of the city centre rather than a factor significant for their businesses (similarly as public transport accessibility). This is also shown by a study of the location preferences of "professional" and "creative" advanced business services, neither of which found this component to be important (Smętkowski et al., 2019).

It is worth noticing that the variables that did not differentiate the companies' choice of location were the company's age, office size, and cost of office space. Thus, the research did not support the incubation function, although this could be because of sample selection (excluding sole traders). On the other hand, the lower rental prices, on average, in the SBD $\left(€ 15\right.$ per $\mathrm{m}^{2}$ compared to $€ 22$ per $\mathrm{m}^{2}$ in $\mathrm{CBD}$ ) seem to have compensated for weaker transport accessibility and lower availability of urban services. Therefore, the companies' assessment of the cost attractiveness of both districts was similar. It was quite surprising that the importance of face-to-face contacts with customers did not differentiate the areas. This might reflect a change in the model of those contacts because of the technological revolution. As the research showed, despite the higher prestige attached to CBDs, that advantage over SBDs was quite small. This was a result of the weakness of the post-war reconstruction of the city centre, and it also reflected the assessment of the aesthetic value of the central city expressed by employees, presented in the next section.

\subsection{Employees}

The three main aspects in the questionnaire given to employees were modes of transport in daily commuting, use of local retail and service facilities including a local shopping centre, and opinions about the workplace neighbourhood (see Table 2 in the Supplementary File).

Because of poorer transport accessibility, time travel to work was higher for SBD employees. For almost $20 \%$ of them, it was between one and one and half hours, while more than half of the responders from the CBD declared the time was less than 30 minutes. The share of those who travelled between 60 and 90 minutes was significantly higher for employees in the SBD. Employees at both areas commuted from various city districts and the suburban zone. There was a stronger preference for the SBD in the southern districts (34.4\% compared to $26.7 \%$ ) and a higher share of the suburban zone in the case of CBDs ( $12.2 \%$ compared to $7.6 \%$ ).

When asked about the most important mode of transport in their daily commuting, most responders in both areas indicated some sort of public transport, usually bus and subway, but there were more in the CBD. In the SBD, the most popular mode was a car (27.7\%); this was in third place for employees in the CBD (14.9\%), after bus and subway. Statistically, there was a significant difference in employees' preference for rail; it was much more popular among employees in the CBD.

In both business areas, employees visited local shopping centres with a similar frequency, and in both cases almost one fourth said they do not visit the local shopping centre at all. More popular were service and retail outlets close to their workplace but outside the shopping centre. Almost $23 \%$ of responders in the SBD declared that they do not visit such outlets, while in CBD the share was only $5 \%$. On the other hand, every third respondent from the CBD visited local shopping and service outlets at least once a day, while in the SBD it was only one in ten. In both areas, the most popular time to visit a local shopping centre during workdays was on the way home from work. In the CBD, such behaviour was cited by $31 \%$ of responders while in the SBD it was $57 \%$. In addition, the shopping centre in the city centre was also frequently visited on the weekends (33\%) and in employees' free time during the workday (19\%). In terms of visiting local shops outside the shopping centre, the most popular were visits on the way home from work. However, workers from the SBD also made such visits during working hours. Those in the CBD made such visit on their way from home to work. Similar to the case of the local shopping centres, visits in free time during working days were significantly more popular among responders working in the CBD (14\%) than in SBD (4\%).

Shopping visits in the local centre were longer in the SBD: $69 \%$ of the responders said they spent between 15 and 60 minutes in the shopping centre. In the CBD, the analogous value was only $44 \%$, and $24 \%$ said that their average visit took less than 15 minutes (compared to only 
$8.1 \%$ from those in the SBD). There were no statistically significant differences between the two districts in terms of time spent shopping in stores nearby the workplace outside the shopping centre.

The stores in the local shopping centres visited most often by employees in both areas were fashion shops (clothes, shoes, accessories) visited by $47 \%$ of all responders. Shopping centre hypermarkets and restaurants were much more popular among employees in the SBD. This disproportion can be explained by the rich and diverse service and retail offers outside the local shopping centre in the city centre and a significantly smaller number of alternative shopping locations outside the shopping centre in SBD. This was confirmed by the differences between the two business areas in terms of the frequency of visits to service and retail outlets outside the shopping centre. In all retail categories, employees of the CBD visited such stores more often than responders from the SBD. In almost all types of stores, the differences between the two areas were statistically significant (the exceptions were fitness clubs, restaurants, fastfood restaurants, and other food and beverages units).

The greater service and retail offerings outside the shopping centre in the CBD was the reason for the more frequent visits to stores outside the shopping centre than inside. The exceptions were fashion and electronic equipment stores and cinema. Those in the city centre shopping site were visited much more often than those outside the shopping centre since the latter were rather scarce. In the SBD, the situation was much more diversified. While the cinema, fast-food restaurants, bookstores, fashion stores, and electronic equipment shops were visited more often in the local shopping centre, outlets like grocery stores, pharmacies, newsstands, restaurants, fitness clubs, banks, and ATMs were visited significantly more often outside the shopping centre. It is also worth noting that for the SBD, the analysis did not reveal a division between employees who visited the local shopping centre and those who prefer stores outside the shopping centre. Instead, the division was between those who shopped near their workplace (67.7\%) and those who did not (14.6\%), regardless of the stores' location. In the CBD, the situation was slightly different: $77.4 \%$ of responders shopped in the local shopping centre and the stores outside the shopping centre, while $17 \%$ shopped only outside the shopping centre.

Despite high popularity as a shopping destination, in both business areas the local shopping centre was not perceived as an appropriate or convenient place for business meetings (including working meetings with co-workers). However, the shopping centre in SBD was significantly more popular in this respect than the shopping centre in CBD. In both areas, restaurants and cafes near the workplace were much more popular.

The quality of workplace surroundings was assessed more highly by employees from the CBD. Out of nine criteria, in only one (availability of green areas) was the SBD assessed higher than the CBD. The largest differ- ences were in the organisation of transport; the availability of restaurants, cafes, shops, service units and public services; and public realm supporting and encouraging leisure and social interactions. However, since half of the $\mathrm{CBD}$ responders lived within 30 minutes travel time of their workplace, it is possible that they used the city centre retail and service often regardless of where they work. This factor may increase the share of positive assessments of the CBD. The city centre also gained more positive assessments from employees in terms of safety, although police statistics reveal that central districts have the highest number of reported crimes. On the other hand, poor transport arrangements in SBD might have decreased perceived levels of safety because of numerous unregulated interactions between pedestrians and vehicles.

The discriminant analysis of the questionnaire results enabled building a model with a strong discriminant power (Wilks' lambda 0.737, p < 0.000). That indicates an even greater differentiation between the areas in terms of the spatial behaviours and preferences of employees than of the companies. The model allowed the proper assignment of responders to one of the business areas for $70.6 \%$ of employees from the SBD and for $88.2 \%$ for the CBD.

The model indicates that the key differences between the two areas resulted from their diverse transport accessibility and different levels and types of agglomeration economies, which translated into different roles for the local shopping centres (see Table 2). Employees of companies in the CBD benefitted from better organisation of transport in the city centre. Thus, they spent less time on commuting, used rail more often, and assessed the area as better organised in terms of transport. They also visited electronic equipment stores outside the shopping centre significantly more often and the local shopping centre on weekends, and they organised business meetings in cafes and restaurants outside the shopping centre. On the other hand, the frequency of visits to grocery stores in the local shopping centre was significantly higher among SBD employees.

\section{Discussion}

The results of the analysis reveal a complex picture of the business districts in Warsaw. In terms of the differences between the CBD and the SBD, the city resembles metropolises in highly developed countries only partially. In addition, some of the research hypothesis based on the review of literature about the post-socialist metropolis could not be fully confirmed.

In terms of the assumed impact of the weak city centre $(\mathrm{H} 1)$-its insufficient prestige and limited potential for creating benefits from face-to-face interactionsthe research revealed that the prestige advantage of the CBD was statistically significant but relatively poor. This was especially the case in the context of negative associations with the SBD because of traffic congestion. 
Table 2. Classification functions of the discriminatory model.

Classification function

CBD

SBD

Transport accessibility

Commuting time

3.351

3.744

Rail

$-1.974$

$-3.843$

Workplace surroundings well organised in terms of transport

2.803

1.875

\section{Agglomeration economy}

Shopping outside the shopping centre on weekends

Shopping in a grocery store in the shopping centre

Shopping in electronic equipment stores outside the shopping centre

Business meetings outside the shopping centre

Model summary

Wilks' lambda $=0.73694$

$F(7,188)=9,5872, p<0.000$

The analysis did not reveal any greater presence of headquarters or companies preferring face-to-face contacts in the CBD. This was indeed a result of the weakness of the post-war reconstruction of the city centre, and it was also reflected, among others, in the assessment of the aesthetic value of the central city area expressed by employees. Therefore, we consider the first hypothesis confirmed to a large extent.

The research partially confirmed the second hypothesis $(\mathrm{H} 2)$ regarding the impact of the dominance of the foreign capital companies on the development process and structure of business districts in Warsaw. The analysis did not reveal any greater presence of control functions in the CBD or the prevalence of more routine services in the SBD. The importance of the availability of parking for employees and clients was similar in both areas, and-contrary to expectations-it was even more important for companies in the SBD. However, the accessibility of diverse types of transport indicates very clear differences in the relations of companies in both business areas. In the CBD, the role of national contacts, based on rail accessibility, plays a greater role, while in the SBD, more significant are international relations, based on air transport. Proximity to the airport proved to be especially attractive for the SBD location of the headquarters of international companies and also for the CEE region.

The third hypothesis $(\mathrm{H} 3)$, regarding the lack of differences between business districts in terms of urbanisation and localisation type of agglomeration, is also only partially confirmed. On the one hand, specific preconditions of urbanisation economies in the SBD could be considered confirmed, since in both business areas certain urbanisation economies were visible based on the opinions of the enterprises. On the other hand, urbanisation economies took different forms in the two districts. The CBD offered greater diversity and density in terms of services, retail, culture, and entertainment availability as well as vivid public spaces facilitating leisure and informal social interactions, while the SBD had greater proximity to suppliers and a local shopping centre.

The last hypothesis $(\mathrm{H} 4)$, underlining the similar significance of private cars in commuting, has not been confirmed. The CBD had a substantial advantage in terms of public transport and rail accessibility, while the SBD was more accessible by car because of the greater availability of parking for employees and proximity to the highway ring road. The superiority of the CBD in terms of transport accessibility was mainly caused by the unplanned and poorly organised spatial structure of the SBD, characterised mainly by significant negative agglomeration externalities in the form of traffic congestion, which had critical effects on both private cars and public transport. Despite the traffic and because of poorer public transport service, employees from the SBD commute by car more often than those from the CBD. Thus, the availability of parking becomes a significant attractiveness factor. The popularity of the car is increased by proximity to the highway ring road, which allows commuters to bypass the congestion. However, this applies only to employees who live in districts served by the highway, i.e., about $15 \%$ of the SBD responders. As a result of access to diverse forms of transport, the two areas operate with different ranges of labour markets defined by the daily commuting. It is metropolitan in the case of the CBD, and sectorial focused on the southern part of the city and the southern suburban zone in the case of SBDs (JLL, 2016). This transport specificity of the SBD is quite uncommon for business districts in Europe, since such areas are usually planned and designed in line with transit-oriented development (TOD; Calthorpe, 1993). Another example of such unusual organisation of transport in the SBD is Dublin (Smętkowski et al., 2020). As a result, both cities (Warsaw and Dublin) face similar traffic congestion and significant commuting time. It is of course not surprising that disobeying the TOD rules reduces the accessibility of transport and increases the costs for companies and 
employees. As a result, and despite living and working in the same city, they spend up to three hours every day commuting. Lack of effective spatial planning and neoliberal market-driven development of the whole reveals negative agglomeration externalities (Büdenbender \& Aalbers, 2019).

Several other factors did not differentiate the two areas: proximity to clients, competitors, and same sector companies; the sources of the location attractiveness; and company characteristics such as age, office space size, and orientation on business-to-business clients. There were no significant differences in terms of the cost of office space. This does not mean that the prices in both areas were at the same level. In the CBD, they were significantly higher. It does mean that, in both districts, the prices were commensurate with the business conditions offered to companies. In the city centre, higher prices for office space were an acceptable cost for greater transport accessibility, while less expensive office space in the SBD was partial compensation for worse traffic conditions. Furthermore, the role of "soft" location attractiveness was similarly low in both areas, especially for companies. This probably results from the fact that employers focused on providing an adequate working environment in the form of office space rather than broader workplace surrounding (Smętkowski et al., 2019).

\section{Conclusions and Recommendations}

The two business districts in Warsaw manifest both similarities and differences, although the latter are more numerous. The similarities and trade-offs for location attractiveness (cost of office space, soft location factors, proximity to clients and competitors, and basic company characteristics) suggest that there is no hierarchical relation between the $C B D$ and SBD and the latter is a functional extension of the city centre rather than a competing business area. The most significant differences between the two Warsaw business areas were their perceived attractiveness, company characteristics and employees' behaviours and opinions with respect to space. The two main domains of the differences are summarised as transport accessibility and agglomeration economies (see Table 3).

While the central business area was quite accessible by rail and public transport, the SBD was struggling with serious traffic congestion. Its employees were to a large extent dependent on car transport while external accessibility was provided mainly by the nearby ring road and airport. In terms of agglomeration economies, a diversified city centre provided a rich offer of services for both businesses and employees. For employees, it also offered access to many retail and catering opportunities, as well as vivid public spaces that enabled social interactions and leisure. In the SBD, such infrastructure was significantly less available. This was only partially compensated by the local shopping centre.

The analysis of the two business districts in Warsaw revealed that the development of business areas in a post-socialist city with a neoliberal model of spatial planning only partially follows the development of spatial patterns and characteristics of business areas in Western European metropolises. The main similarities between the models in the literature and the Warsaw case were access to transport and the attractiveness of the city centre based on the urbanisation of economies. In other aspects, the Western European model was not confirmed in the reality of the post-socialist metropolis. In addition, only part of the hypothesis that the differences between the CBD and the SBD were because this is a post-socialist metropolis was confirmed, specifically, those related to prestige and car accessibility for customers and employees of both areas and urbanisation economies in the SBD.

The Warsaw case shows many negative consequences of ineffective and highly liberal spatial planning policies in an emerging metropolis exposed to globalisation and market forces. Apart from the general recommendation to direct and guide the development of business areas by consistent and properly equipped spatial planning policy, we also developed some specific rec-

Table 3. The main differences between the two business areas in Warsaw.

CBD

SBD

Transport accessibility

Internal (relations within the metropolitan area)

External (relations with other cities)

Rail

Urban services availability

Wide offer of retail, services, catering

Public space that enables social

interaction and leisure
Parking for employees, highway ring road

Airport, highway ring road

Proximity to suppliers

Shopping centre 
ommendations for urban planning policy and practice aimed at providing more sustainable and coordinated urban development. In planning the creation and/or the development of secondary SBDs, adopting the approach of TOD is recommended to avoid car traffic congestion which may create significant financial and time travel costs, mostly for the offices' employees.

The study shows that rich retail and service offers and high-quality public space might not be the most important factors of a business district's attractiveness to companies and employees. However, deficiencies in these areas might significantly diminish such attractiveness. It is thus important to promote mixed-use development with appropriate volume and distribution of quality public spaces in SBDs (Booth et al., 2002). This may create an attractive working environment not only for employers but also for employees who would not be forced to use shopping centres as the most accessible-or even the only-substitute for public space (Karrholm, 2016).

The study also proved the significant and increasing role of air transport in business relations. Cities that are important locations for regional headquarters or for subsidiaries of international companies especially could benefit from well-planned business districts and creating favourable conditions for service companies close to airports (Freestone \& Baker, 2011) in areas that usually exclude residential development.

It is still difficult to indicate the most appropriate or beneficial spatial structure of the urban commercial space. Although the concentrated, cluster type of urban business district may create significant traffic congestion, especially when they are not properly planned, it also brings considerable agglomeration economies. Despite the development of ICT tools, face-to-face contact and proximity to clients or suppliers still play a significant role in increasing the attractiveness of a business areas' location. It is also worth noting that the Covid-19 pandemic may change this picture by increasing the importance of remote work and ICT-based contacts with clients.

Although this research provides many valuable conclusions, it also has some limitations that should be considered. The results refer to Warsaw, so they can only be extrapolated to other post-socialist metropolises to a limited extent. A post-socialist heritage is not the only factor that determines the trajectory of the development of a city's business areas. The role of spatial planning policy, as well as such factors as the shape of the transport network and the location of airports (which in Warsaw is located relatively close to the city centre) cannot be omitted. We are also aware that we present a static picture of a phenomenon that is very dynamic in nature and that, since 2018 , the situation in both business areas (including their relative attractiveness) might have changed. In addition, both survey samples were not representative. Thus, their results cannot be treated as a universal illustration of the behaviours and opinions of the companies and their employees in the two business areas of Warsaw. The size and differentiation of the employee sample did not allow for the control of variables that might have had some impact on the responders' opinions, e.g., age, place of residence, or job position.

The analysis of the two business districts revealed a broad area of possible future research, of which the most obvious are studies that compare the results for Warsaw with similar analysis conducted in other CEE countries. Especially valuable might be comparisons with other post-socialist capital cities and countries in terms of their approaches to spatial planning. It would also be worth comparing the opinions of managers and employees in the same company about the office's location attractiveness. Interesting results may also come from a more detailed analysis of companies (and their employees) that have recently changed their location. They might have more in-depth insights about the attractiveness of available office locations. A promising expansion of our research would be to add a dynamic aspect, i.e., to analyse changes in the characteristics and attractiveness of the two business areas over time. Finally, as already mentioned, (post-)pandemic reality may bring a significant change in terms of the role of specific location factors, such as transport accessibility or proximity to the airport, clients, and suppliers.

\section{Acknowledgments}

The article presents the results of the research project "New economic spaces of the metropolis-Structure, functions and linkages of business districts on the basis of the emerging Warsaw metropolis" financed by the Polish National Science Centre, granted on the basis of decision number DEC-2014/15/B/HS4/02047.

\section{Conflict of Interests}

The authors declare no conflict of interests.

\section{Supplementary Material}

Supplementary material for this article is available online in the format provided by the authors (unedited).

\section{References}

Arrow, K. J. (1962). The economic implications of learning by doing. The Review of Economic Studies, 29(3), 155-173.

Beaverstock, J. V., Taylor, P. J., \& Smith, R. G. (1999). The long arm of the law: London's law firms in a globalising world economy. Environment and Planning $A$, 31(10), 1857-1876.

Benko, B. (1993). Geografia technopolii [Geography of technopoles]. Wydawnictwo Naukowe PWN.

Bole, D. (2010). Secondary business districts in Ljubljana. Analysis of conditions and assessment of planned development. Urbani Izziv, 21(1), 78-93.

Bontje, M., \& Burdack, J. (2005). Edge cities, European- 
style: Examples from Paris and the Randstad. Cities, 22(4), 317-330.

Booth, G., Leonard, B., \& Pawlukiewicz, M. (2002). Ten principles for reinventing suburban business districts. Urban Land Institute.

Büdenbender, M., \& Aalbers, M. B. (2019). How subordinate financialization shapes urban development: The rise and fall of Warsaw's Służewiec business district. International Journal of Urban and Regional Research, 43(4), 666-684.

Buisson, M. A., Mignot, D., \& Aguilera-Belanger, A. (2001). Métropolisation et polarités intra-urbaines. Le cas de Lyon [Metropolisation and intra-urban polarities. The case of Lyon]. Revue d'Economie Régionale et Urbaine, 2, 271-296.

Calthorpe, P. (1993). The next American metropolis: Ecology, community, and the American dream. Princeton Architectural Press.

Capelle-Blancard, G., \& Tadjeddine, Y. (2010). The urban location of financial activities (Working Paper). University Paris 1 Panthéon-Sorbonne.

Castells, M. (1998). The information age: Economy, society and culture-The rise of network society. Blackwell.

CB Richard Ellis. (2011). Business footprints: Global office locations 2011.

Criekingen, M., Bachmann, M., Guisset, C., \& Lennert, M. (2007). Towards polycentric cities. An investigation into the restructuring of intra-metropolitan spatial configurations in Europe. Belgeo, 1, 31-50.

Doloroux, D., \& Shearmur, R. G. (2013). Innovation strategies: Are knowledge-intensive business services just another source of information? Industry and Innovation, 20(8), 719-738.

Dorocki, S., Raźniak, P., \& Winiarczyk-Raźniak, A. (2019). Changes in the command and control potential of European cities in 2006-2016. Geographia Polonica, 92(3), 275-288.

Dyker, D. A., \& Radosevic, S. (Eds.). (1999). Innovation and structural change in post-socialist countries: A quantitative approach. Springer.

ESPON. (2010). FOCI: Future orientation for cities. https://www.espon.eu/sites/default/files/ attachments/FOCl_draft_final_report_Scientific Report.pdf

Filion, P. (2000). Balancing concentration and dispersion? Public policy and urban structure in Toronto. Environment and Planning C, 18(2), 163-189.

Florida, R. (2005). Cities and creative class. Routledge.

Freestone, R., \& Baker, D. (2011). Spatial planning models of airport-driven urban development. Journal of Planning Literature, 26(3), 263-269.

Fujita, M., \& Ogawa, H. (1982). Multiple equilibria and structural transition of non-monocentric urban configurations. Regional Science and Urban Economics, 12(2), 161-196.

Fujita, M., \& Thisse, J. F. (2002). Economics of agglomeration: Cities, industrial location, and globalization.
Cambridge University Press.

Garreau, J. (1991). Edge city: Life on the new frontier. Random House.

Giuliano, G., Redfearn, C., Agarwal, A., \& He, S. (2012). Network accessibility and employment centres. Urban Studies, 49(1), 77-95.

Glaeser, E. L. (2011). Triumph of the city: How our greatest invention makes us richer, smarter, greener, healthier, and happier. Palgrave Macmillan.

Gorzelak, G., \& Smętkowski, M. (2012). Warsaw as a metropolis-Successes and missed opportunities. Regional Science Policy \& Practice, 4(1), 25-45.

Halbert, L. (2007). From sectors to functions: Producer services, metropolisation and agglomeration forces in the lle-de-France region. Belgeo, 1, 73-94.

Hall, P. (1999). The future of cities. Computers. Environment and Urban Systems, 23, 173-185.

Hall, P., \& Pain, K. (Eds.). (2006). The polycentric metropolis: Learning from mega-city regions in Europe. Earthscan.

Hardt, M., \& Negri, A. (2000). Empire. Harvard University Press.

Hermann, M., Pentek, T., \& Otto, B. (2016). Design principles for industry 4.0 scenarios. In Proceedings of the 2016 49th Hawaii International Conference on System Sciences (HICSS) (pp. 3928-3937). IEEE Computer Society.

Jacobs, J. (1961). The death and life of great American cities. Random House.

Jacobs, J. (1969). The life of cities. Random House.

JLL. (2016). Służewiec 2.0. Perspektywy rozwoju największej dzielnicy biurowej $w$ Polsce [Sluzewiec 2.0. Development perspectives of the largest office district in Poland].

Karrholm, M. (2016). Retailising space: Architecture, retail and the territorialisation of public space. Routledge.

Komninos, N. (2008). Intelligent cities and globalisation of innovation networks. Routledge.

Komornicki, T. (2011). Przemiany mobilności codziennej Polaków na tle rozwoju motoryzacji [Changes in the daily mobility of Poles in relation to the development of the automotive industry]. IGiPZ PAN.

Korcelli-Olejniczak, E. (2007). Berlin and Warsaw: In search of a new role in the European urban system. Journal of Housing and the Built Environment, 22(1), 51-68.

Kotler, P. (1994). Marketing management. Analysis, planning, implementation, and control (8th ed.). PrenticeHall.

Lang, R. (2003). Edgeless cities: Exploring the elusive metropolis. Brookings Institution Press.

Marshall, A. (1920). Principles of economics. Palgrave Macmillan.

Martinelli, F., \& Moulaert, F. (1993). The location of advanced producer services firms: Theory and illustrations. Geographische Zeitschrift, 81, 1-17.

McLachlan, G. J. (2004). Discriminant analysis and statis- 
tical pattern recognition. Wiley.

Polanyi, M. (1958). Personal knowledge: Towards a postcritical philosophy. University of Chicago Press.

Ratcliffe, J., Stubbs, M., \& Keeping, M. (2009). Urban planning and real estate development (3rd ed.). Routledge.

Raźniak, P., Dorocki, S., \& Winiarczyk-Raźniak, A. (2018). Central European cities as command and control centers in a time of economic crisis. Acta Geographica Slovenica, 58, 101-110.

Romer, P. M. (1986). Increasing returns and longrun growth. Journal of Political Economy, 94(5), 1002-1037.

Rutten, R., \& Boekema, F. (2012). From learning region to learning in a socio-spatial context. Regional Studies, 46(8), 981-992.

Śleszyński, P. (2004). Kształtowanie się zachodniej części centrum Warszawy [Formation of the western part of the Warsaw city centre]. IGiPZ PAN.

Śleszyński, P. (2007). Gospodarcze funkcje kontrolne w przestrzeni Polski [Economic control functions in the space of Poland]. IGiPZ PAN.

Smętkowski, M. (2009). Nowe relacje między metropolią a regionem: od terytorialnej do sieciowej organizacji przestrzeni [New relations between the metropolis and its region: From territorial to network organization of space]. In B. Jałowiecki (Ed.), Czy metropolia jest miastem? [Is the metropolis a city?] (pp. 26-49). Wydawnictwo Naukowe Scholar.

Smętkowski, M., \& Celińska-Janowicz, D. (2014). Dwubiegunowość przestrzeni biurowej w WarszawiePorównanie Centralnego i Mokotówskiego Obszaru Biznesu [Bipolarity of office space in WarsawComparison of the central and Mokotów business areas]. In A. Wolaniuk (Ed.), Centra i peryferie w okresie transformacji ustrojowej [Centres and peripheries in the period of systemic transformation] (pp. 205-216). Wydawnictwo Uniwersytetu Łódzkiego.

Smętkowski, M., Celinska-Janowicz, D., \& Wojnar, K. (2019). Nowe przestrzenie gospodarcze metropolii. Struktura, funkcje i powiqzania obszarów biznesu w
Warszawie [New economic spaces of the metropolis. Structure, functions, and connections of business areas in Warsaw]. Wydawnictwo Naukowe Scholar.

Smętkowski, M., Moore-Cherry, N., \& Celińska-Janowicz, D. (2020). Spatial transformation, public policy and metropolitan governance: Secondary business districts in Dublin and Warsaw. European Planning Studies, 29(7), 1331-1352. https://doi.org/10.1080/ 09654313.2020 .1856346

Soja, E. W. (2000). Postmetropolis-Critical studies of cities and regions. Blackwell.

Spencer, G. M. (2015). Knowledge neighbourhoods: Urban form and evolutionary economic geography. Regional Studies, 49(5), 883-898.

Stanilov, K. (Ed.). (2009). The post-socialist city: Urban form and space transformations in central and eastern Europe after socialism. Springer.

Sýkora, L. (2009). Post-socialist cities. In R. Kitchin \& N. Thrift (Eds.), International encyclopedia of human geography (8th ed., pp. 387-395). Elsevier.

Sýkora, L., \& Bouzarovski, S. (2012). Multiple transformations: Conceptualising the post-communist urban transition. Urban Studies, 49(1), 41-58.

Tabachnick, B. G., \& Fidell, L. S. (2019). Using multivariate statistics (7th ed.). Pearson.

Taylor, P. J. (2001). Specification of the world city network. Geographical Analysis, 33(2), 181-194.

Taylor, P. J., \& Derudder, B. (2016). World city network (2nd ed.). Routledge.

Taylor, P. J., Derudder, B., Hoyler, M., Pain, K., \& Witlox, F. (2010). European cities in globalization. In P. J. Taylor, P. Ni, B. Derudder, M. Hoyler, J. Huang, \& F. Witlox (Eds.), Global urban analysis. A survey of cities in globalization (pp. 114-136). Earthscan.

Tsenkova, S., \& Nedović-Budić, Z. (Eds.). (2006). The urban mosaic of post-socialist Europe: Space, institutions and policy. Physica-Verlag.

Węcławowicz, G. (1996). Contemporary Poland. Space and society. UCL Press.

Wojnar, K. (2016). Polska klasa kreatywna [Polish creative class]. Narodowe Centrum Kultury.

\section{About the Authors}

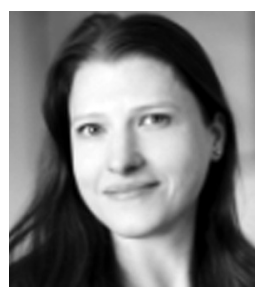

Dorota Celińska-Janowicz holds a PhD in Earth Sciences (specialty in Geography) and is an assistant professor at the Centre for European Regional and Local Studies at EUROREG, University of Warsaw. She graduated in geography and spatial economy at the University of Warsaw and was awarded several post-doc scholarships (University of Vienna, Free University of Berlin, University of Oxford). Her area of expertise is economic geography, retail geography, urban studies, and regional and local development.

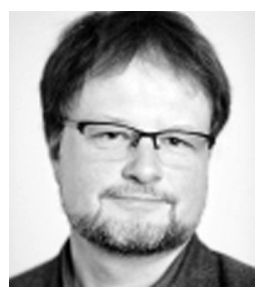

Maciej Smętkowski holds a PhD in Earth Sciences (specialty in Economic Geography). He is an associate professor at the Centre for European Regional and Local Studies (EUROREG), University of Warsaw. He has participated in a number of research projects on metropolisation processes, instruments of regional policy, trans-border co-operation, and evaluation of pre-accession aids and structural funds of the UE. He is a chairman of the Polish Section of the Regional Studies Association. 
Katarzyna Wojnar is an assistant professor at the Centre for European Regional and Local Studies at EUROREG, University of Warsaw. She received a PhD in Earth Sciences and Geography for the thesis "The creative capital as a factor of competitiveness of Polish cities: conditions and importance in regional development." She received an MA in spatial planning (2008) and social policy (2005) at the University of Warsaw and in European political sociology (2006) at Högskolan Dalarna in Sweden. She is an expert in the research of urban creativity and culture policies. 